\title{
Considerations on human sexuality and sexual ethics in the context of child sex abuse
}

\author{
Grażyna Jarząbek-Bielecka', Magdalena Pisarska-Krawczyk ${ }^{2,3}$ \\ ${ }^{1}$ Clinic of Gynecology of Department of Perinatology and Gynecology, Division of Developmental Gynecology \\ and Sexuology of Department of Perinatology and Gynecology, University of Medical Sciences, Poznan, Poland \\ ${ }^{2}$ Higher Vocational State School in Kalisz, Poland \\ ${ }^{3}$ Department of Maternal and Child Health, University of Medical Sciences, Poznan, Poland
}

\begin{abstract}
When investigating the concept of sexuality, due consideration should be given to novel humanistic approaches that deeply concern philosophical and ethical aspects of the individual as well to the usual medical, psycho-social, and legal issues. Modern-day sexology seeks for an exchange of experiences, study outcomes, and subject matter, which aims to serve towards an understanding of human sexuality from puberty onwards; indeed, such a perspective can be used in children suffering from sexual abuse/violence.
\end{abstract}

KEY WORDS: sexology, sexual ethics, children's sexual abuse.

ADDRESS FOR CORRESPONDENCE: Magdalena Pisarska-Krawczyk, Higher Vocational State School in Kalisz, 4 Nowy Świat Street, 62-800 Kalisz, Poland, e-mail: magmp@op.pl

The ways in which harm/evil arises whenever sexual abuse of children occurs is complex, as is its actual reality. It should be remembered that when such abhorrent issues are considered, both victim and perpetrator need to be taken into account, respectively: "dramatis personae" and "perperatos". The context of this problem is also profoundly historical. Throughout history, sexual freedom has been frequently misunderstood, leading to tragedy. Cardinal Stefan Wyszynski delivered his telling pronouncement on this matter: "The sanctity of the human person must be protected and not devalued". Sexuality is one of the fundamental endowments of the human condition, and this bounty becomes depraved and ruined upon its abuse. The scale and the burden of harm to innocent children are enormous, and become manifest in all the subsequent stages of the child's development. A child is a person with their own dignity, which (....) should be respected; sexual child abuse strikes down the very dignity of the child as well as its innocence in all the ways as understood within the context of Freudian psychoanalysis. Child sex abuse is an evil, and as the worst possible harm that can befall a child, it can never be held as being a "forbidden normality" [1-7].
Human sexuality cannot be considered without taking into account somatic and biopsychosocial conditions, along with sexual ethics and the great works of John Paul II, Joseph Tischner, or other renowned ethicists. The issue of ethics within the practice of sexology or sexual therapy is a very complex subject. The diverse types of deontic norms defined in various laws/codices are one thing, but each individual case that a sexologist has to deal with is another. Their specific class, which potentiates the tension existing between generality of norms with given circumstances, belongs to the realm of moral conflicts. Upon stressing the importance of the sexologist being reflective, in terms of general and specific ethics, the inalienable role of moral awareness and the physician's conscience should nevertheless be remembered, which allows optimal choices to be made concerning therapy, treatment, and the wellbeing of the person-patient, without the physician imposing their own axiomoral and normative standards. From the ethics of ancient history, making such choices was termed phronesis (i.e. practical wisdom). Indeed, sexologists should be phronetic. It should be noted that lying behind concrete decision-making are perceptions of humanity 
as philosophical beings, often mired within global and ideological contexts. From this arises the importance of studying the relationship between ethics and sexology (and gynaecology). The subject of development and sexual health thereby merits further investigation within the context of sexual ethics considered in both descriptive and prescriptive terms [1-5]. From the viewpoint of women and gynaecology it is, for instance, worth studying the wide-ranging effects of gynaecological status on women's sexuality; in analogous fashion, the same holds true for men and andrology. New questions are posed to the field of ethics arising from the dynamic progress achieved in medicine. This specifically refers to gynaecology, andrology, and sexology; both in their theoretical and therapeutic aspects. The first tier of problem-issues so arising are questions about the existence and possible structure of moral norms in sexology. What sets a general norm for morality regarding a person's sexual behaviour? Is it respecting human dignity and freedom, the extent of tolerance and social awareness or transcendent or immanent considerations? These are undoubtedly wide-ranging problems for meta-ethics and applied ethics. Ethical questions in sexology therapy concern respecting patients' axiomatic hierarchy, suspending one's own beliefs, and in contemporaneously and inevitably reconciling, to some extent, the patient-physician confrontation in ethics; this being psychologically quite understandable. Such issues broadly fall within the scope of medical philosophy, bioethics, and finally medical ethics. The dispute between teleologism (e.g. ED Pellegrino) and counter-modernism (e.g. RM Veatch) or fashionable principlism (e.g. TL Beauchamp or JF Childress) define the remit of contemporary disputes surrounding the fundamentals of medical ethics.

Taken from the viewpoint of medicine, sexology, adolescent gynaecology, and ethics, the sexual abuse of children is evil and cannot be justified; even by pointing to past historical or cultural precedents.

Any positive assessments of morality derived from whenever there is some positive behaviour found in individual cases, falls into a double error. Firstly, this is due to the simple universalisation of partial assessments functioning at the factual level, and secondly in the naturalistic error as defined by GE Moore. Normativity cannot be derived from factuality (because values do not directly arise from facts), which we know from Hume's "guillotine" (i.e. no breaching of the gap between is-ought statements). Normative resolutions must thus be sought for in completely different areas, which cannot be shown in any consideration on sexual child abuse; as is discussed here. Within the field of sexology, in the context of the law and the judiciary, evidence shows that legal regulations are being constantly clarified and improved (in accordance with the care over human sexuality rights), and which are aimed at sorting out this entire problem area. The basic issue is the concern over children's normal psychosexual development undisrupted by abuse. Moral norms protect against such events happening based on arguments of dignity and that of the person. This is in full harmony with the fields of sexology, gynaecology, and developmental psychology.

Studies have been undertaken demonstrating the importance of the sexual morality ethos from the viewpoint of sexology (including judicial/legal sexology) as well as a normative understanding of sexual ethics. Sexual behaviour falls within the jurisdiction of the law. Legal regulations are in place that forbid certain sexual acts that carry the threat of criminal sanction. Many studies have also shown that sexuality is inherently linked with responsibility. In these, the relevant legislation on sex and responsibility are emphasised in relation to sexual abuse. Sexual offences are contained within Chapter XXV in articles 197 to 205 of the Criminal Code. According to Joseph Tischner: "Sex is a certain mood, feeling, experience, and carnality but it is also a type of responsibility that a person bears into the world". Entering into deeply intimate areas of human existence creates a very special type of responsibility towards one's partner. One can say that the deeper such a contact is, then so is the responsibility borne. Within the sphere of love and sex its extent becomes particularly high, because of the ease in which the other person can be injured (as in "Love and Responsibility"; a book by Karol Wojtyla, which reflects these issues raised here) [3-8].

Human actions directed at satisfying/gratifying "sexual needs" are complicated and involve various mechanisms that go far beyond sexuality itself. In phylogenetic terms, only in the case of the human species it is thus considered that erotica involving sexuality falls within the sphere of feelings, intellect, and that of the psyche. It happens that a person's sexual life functions within their erotic space. This raises the question on how the relationship between eroticism and sexuality is defined in the aforementioned areas, together with issues of health promotion that include mental health.

As much as the twentieth century has witnessed progress made in the pharmacotherapy of sexual dysfunction and the development of diagnostic methods (especially in sexuality neurobiology), constituting the medicalisation of sexology, the twenty-first century has in a way reverted back to embracing the multidisciplinary approach to sexology. For example, there have been innovative studies on the sexuality of disabled people now demonstrating that significant aspects of sexuality are a person's dignity and the ethical dimension, and not just a neglect of psychosocial conditions being an obstacle to solving patient problems as well as the promotion of sexual health and health in general. Studies have shown the importance of the broadly understood personalistic trend in sexual ethics and sexology (i.e. the persona est affirmanda principle), although quite obviously strongly reductionist trends will be present. There 
is a tendency to now integrate sexology, according to current recommendations for treating sexual dysfunctions, with sex education programs and partner therapy development, whilst taking into account the traditional integral perspective on human sexuality.

From such a perspective, this approach to sexual problems has a place in any discussion on the type and form of scientific approaches to human sexuality at different stages of life; particularly the psychosexual development aspects. In addition to the medical approach and accounting for psychosocial and legal aspects of human sexuality, an innovative humanistic approach is also worth considering, especially regarding both personalism as a philosophical trend and sexual ethics. Modern-day sexology seeks to exchange experiences, study outcomes and issues, and to facilitate the understanding of human sexuality from when it starts to develop. This multi-faceted outlook permits a broad and comprehensive presentation of issues that in their very nature concern both the spirit (psyche) and the body. Nevertheless, there are other concepts of sexuality, and the concepts put forward in this article represent a specific viewpoint in any discussions on human sexuality; being one of many proposals that investigate the problems and issues as reviewed here $[3,5,8-11]$

\section{DISCLOSURE}

Authors report no conflict of interest.

\section{References}

1. Sultan C. Pediatric and Adolescent Gynecology. Evidence-Based Clinical Practice. $2^{\text {nd }}$, revised and extended edition. Endocr Dev. Basel, Karger 2012 (vol. 22, pp. I-VIII).

2. Jarząbek-Bielecka G. Etyka, bioetyka medycyna [Ethics, bioethics, medicine]. Wydawnictwo Uniwersytetu Medycznego w Poznaniu, Poznań 2015.

3. Stachewicz K. Czy etyka lekarska jest potrzebna? [Is medical ethics needed?]. Available from: https://portal.tezeusz.pl/2006/06/04/ czy-etyka-lekarska-jest-potrzebna/ (accessed: 4 April 2017).

4. Jarząbek-Bielecka G. Nauka o płci [Science about sex]. Wydawnictwo Uniwersytetu Medycznego w Poznaniu, Poznań 2012.

5. Jarząbek-Bielecka G. Seksuologia a etyka seksualna i problem przemocy seksualnej wobec dzieci [Sexology and sexual ethics and the problem of sexual violence against children]. Wydawnictwo Uniwersytetu Medycznego w Poznaniu, Poznań 2009.

6. Jarząbek-Bielecka G, Warchoł-Biedermann K, Jarząbek M, et al. Sexual crimes. Arch Perinat Med 2014; 20: 162-164.

7. Jarząbek-Bielecka G, Borowczyk M, Chmielarz-Czarnocińska A, et al. Badania dotyczące poglądów na temat seksu inspirowane myślą Józefa Tischnera [Research on views on sex inspired by the thought of Józef Tischner]. In: Zagadnienia interdyscyplinarne $\mathrm{w}$ ginekologii praktycznej [Interdisciplinary issues in practical gynecology]. Pisarska-Krawczyk M, Jarząbek-Bielecka G (eds.). Wydawnictwo Państwowej Wyższej Szkoły Zawodowej w Kaliszu, Kalisz 2014.
8. Jarząbek-Bielecka G. Health promotion, ethics and legal aspects in adolescents gynecology and sexology. Arch Perinat Med 2016; 22: 39-42.

9. Jarząbek-Bielecka G, Radomski D, Bielecki M. O opiece ginekologicznej i seksuologicznej nad pacjentką niepełnosprawną (z uwzględnieniem poradnictwa aptekarskiego) [On gynecological and sexological care of a disabled patient (including pharmacy counseling)]. In: Nauka o płci. Zagadnienia wybrane [Science about sex. Selected issues]. Jarząbek-Bielecka G. Wydawnictwo Uniwersytetu Medycznego w Poznaniu, Poznań 2012; 183-207.

10. Radomski D, Jarząbek-Bielecka G. Propozycja standaryzacji opieki seksuologicznej nad pacjentem $\mathrm{z}$ urazem rdzenia kręgowego [A proposal for the standardization of sexological care for a patient with a spinal cord injury]. In: XVI Ogólnopolska Konferencja Naukowo-Szkoleniowa „Polska Seksuologia. XX lat Polskiego Towarzystwa Seksuologicznego”. Warszawa 2011; 1-15.

11. Jarząbek G, Radomski D. Specyfika opieki ginekologicznej i seksuologicznej nad kobietami niepełnosprawnymi w okresie pomenopauzalnym $\mathrm{z}$ uwzględnieniem aspektów etycznych [Dissimilarities of gynaecological and sexological care in handicapped patients after menopause: medical and ethical aspects]. Prz Menopauz 2011; 10: 63-67.

\section{AUTHORS' CONTRIBUTIONS}

GJB, MPK prepared the research concept, collected data, wrote the article and finally approved it. 